\title{
Relationship between infant mortality and altitude in the Northwest region of Argentina
}

\author{
Valeria F. Chapur, B.S. ${ }^{a}$ Emma L. Alfaro, M.D. ${ }^{b}$, Rubén Bronberg, M.D. ${ }^{c}$ and \\ José E. Dipierri, M.D. ${ }^{c}$
}

\begin{abstract}
Introduction. Given its location on the Andes, the Northwest region of Argentina is geographically, socioeconomically, culturally, and biologically heterogeneous, and this is reflected on an infant mortality rate (IMR) that is higher than in any other Argentine region.

Objective. To estimate IMR, neonatal mortality rate (NMR), and post-neonatal mortality rate (PNMR), and to analyze their spatial and temporal variations using secular trends and the relative risk based on altitudinal zones.

Population and method. This was a retrospective, descriptive, correlational study based on birth and death data recorded in the Northwest region of Argentina (1998-2010); IMR, NMR, PNMR, secular trends, and the relative risk of death were calculated by district and altitudinal zone (districts at $<2000$ meters above sea level, lowlands; at $\geq 2000$ meters above sea level, highlands) by means of a cluster analysis.

Results and conclusions. Rates werehigher in the highlands; IMR was $29.8 \%$ (versus $15.6 \%$ in the lowlands); PNMR was 17.7\% in the highlands (versus $5.2 \%$ in the lowlands). In the highlands, there was an annual average reduction of 3.9\% in IMR and of $4.1 \%$ in PNMR; in the lowlands, such reduction was of $7.0 \%$ in IMR and of $9.3 \%$ in PNMR. The relative risk of IMR and PNMR was significantly higher at high-altitude zones. NMR, its secular trend, and the relative risk did not show statistically significant differences between both altitudinal zones.

Key words: infant mortality rate, secular trend, relative risk.
\end{abstract}

http:/ / dx.doi.org/10.5546/aap.2017.eng.462

To cite: Chapur VF, Alfaro EL, Bronberg R, et al. Relationship between infant mortality and altitude in the Northwest region of Argentina. Arch Argent Pediatr 2017;115(5):462-469.

CONICET - INBIA San Salvador de Jujuy.

E-mail address:

Valeria F. Chapur, B.S.: ferchapur@hotmail.com

Funding:

See page 468 .

Conflict of interest:

None.

Received: 9-14-2016 Accepted: 2-20-2017 pathogenic factors, and the physical, biological, and social environment. ${ }^{2}$

In Argentina, over the past two decades, there has been a significant reduction in infant mortality and its components; however, the Northwest region of Argentina (NOA) has historically exhibited higher rates than the Humid Pampa. ${ }^{3}$ In 2010, in Argentina, IMR was $11.9 \%$ and, at a regional level, the highest rate was observed in the Northeast region of Argentina (15.2\%o), followed by the NOA (13.6\%o), Pampa (13.2\%o), Cuyo $(11.4 \%)$, Patagonia $(9.2 \%)$, and the Autonomous City of Buenos Aires $(7.0 \%){ }^{4}$ IMR in the NOA is above the value agreed for the achievement of Millennium Development Goal 4. ${ }^{5}$ Between 2006 and 2010, IMR was alarmingly high in the provinces of Jujuy, Salta, Tucumán, and Catamarca, higher than the national mean rate. ${ }^{6}$

The NOA is made up of the provinces of Jujuy, Salta, Tucumán, Santiago del Estero, Catamarca, and La Rioja. It has a surface of $559864 \mathrm{~km}^{2}$ and represents $14.8 \%$ of the Argentine territory. The presence of the Andes range on the western margin of this region gives rise to an altitudinal gradient that ranges from 5000 to 500 meters above sea level (MASL), resulting in weather, environmental, and production conditions that create a marked heterogeneity in its social, economic, and cultural space. ${ }^{7}$

Different socioeconomic and environmental factors affect infant mortality. Among environmental factors, an increase in infant mortality at high altitude has been verified in different high-altitude ecosystems from the United States, ${ }^{8-10}$ Peru, ${ }^{11}$ Bolivia, ${ }^{12-14}$ and the Himalayas. ${ }^{15}$ Out of the 117 districts comprised 
by the NOA, 17 are above 2000 MASL in the provinces of Jujuy (Santa Catalina, Yavi, Rinconada, Cochinoca, Susques, Humahuaca, Tilcara, Tumbaya, Valle Grande), Salta (Iruya, Santa Victoria, Los Andes, La Poma, Cachi, Molinos), Tucumán (Tafí del Valle), and Catamarca (Antofagasta de la Sierra), and they are characterized by reduced rainfall, intense solar radiation, daily thermal amplitude, and a rugged terrain, all of which influence inhabitants ${ }^{\prime}$ living conditions. ${ }^{16,17}$

Based on this background, the hypothesis is that infant mortality in the NOA should vary depending on the altitude above sea level, among other factors. For this reason, the objective of this study was to estimate IMR, neonatal mortality rate (NMR), and post-neonatal mortality rate (PNMR), and to analyze their spatial and temporal variations using secular trends (STs) and the relative risk (RR) based on altitudinal zones.

\section{POPULATION AND METHODS}

This was a retrospective, descriptive, correlational study based on birth and death data collected for infants of up to 1 year old occurred in the NOA between 1998 and 2010 (Health
Statistics and Information Department of the Ministry of Health of Argentina).

Data were analyzed in reference to the place of residence of the mother. Outcome measures were as follows: a) number of live births; $b$ ) number of infant deaths per period: neonatal (up to 27 days) and post-neonatal (between 28 and 365 days). Districts in the NOA were divided by altitude into locations at less than 2000 MASL (lowlands) and at 2000 MASL or more (highlands).

The following rates were calculated by year, district, and altitudinal zone: 1) IMR (number of infant deaths / number of live births * 1000); 2) NMR (number of neonatal deaths/number of live births *1000); 3) PNMR (number of postneonatal deaths/ number of live births * 1000).

An ST is the variation of mortality by year in a specific location, in this case, the NOA, over the period between 1998 and 2010; RR refers to the size of the infant death trend at 2000 MASL or more compared to that at a lower altitude. Both were calculated using a Poisson regression model, which is adequate for low frequency events. To detect areas where mortality rates vary significantly within the NOA, a cluster analysis was done using the SaTScan v5 software, ${ }^{1,18}$ which

FIGURE 1. Distribution of infant mortality rate, neonatal mortality rate, and post-neonatal mortality rate in the highlands and the lowlands

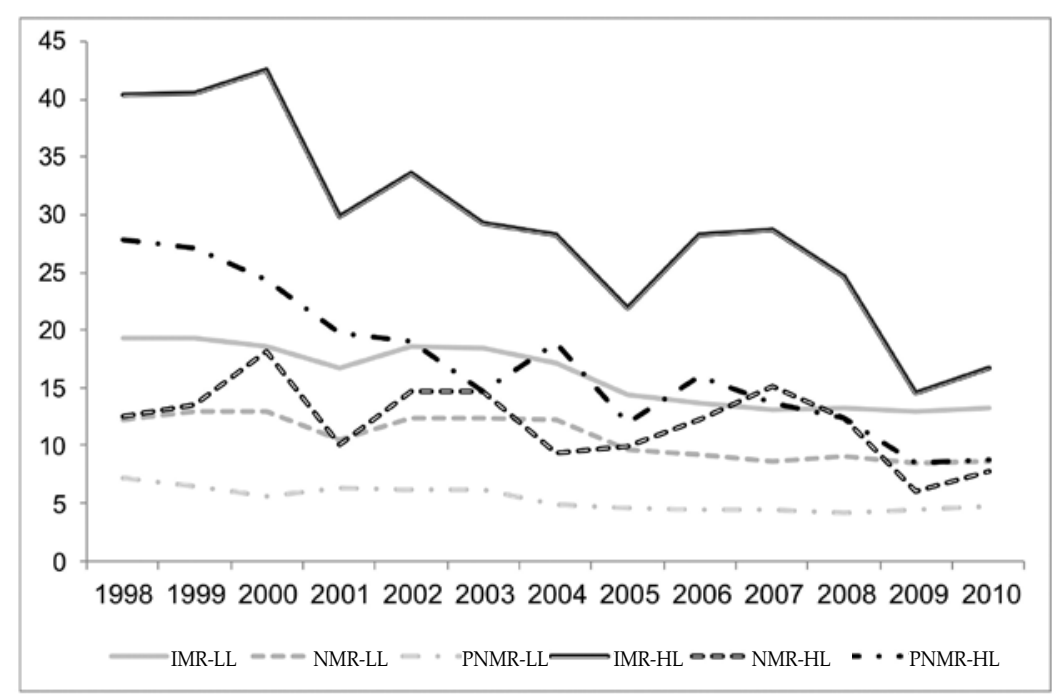

IMR-LL: total infant mortality rates in the lowlands (\%o).

NMR-LL: neonatal mortality rates in the lowlands (\%o).

PNMR-LL: post-neonatal mortality rates in the lowlands (\%o).

IMR-HL: total infant mortality rates in the highlands (\%o).

NMR-HL: neonatal mortality rates in the highlands (\%o).

PNMR-HL: post-neonatal mortality rates in the highlands (\%o). 
is designed to perform spatial and temporal monitoring of the problem under study, in this case, infant mortality and its components. Spatial clusters were detected, and their statistical significance in relation to the NOA's overall rates was verified.

\section{RESULTS}

Between 1998 and 2010, there were 1273438 births and 21077 deaths of infants younger than 1 year old in the NOA. The IMR, NMR, and PNMR were $16.06 \%$, $10.45 \%$, and $5.61 \%$, respectively.

For the total period, IMR was higher in the highlands (29.8\%o) than in the lowlands (15.6\%o); such difference was mainly the result of the post-neonatal component, which was $5.2 \%$ in the populations living at less than 2000 MASL compared to $17.7 \%$ in the highlands. Such differences were statistically significant $(p<0.05)$. NMR was similar in both altitudinal zones (Figure 1).

Figure 1 and Table 1 show that the ST was negative and statistically significant in both altitudinal zones. In the lowlands, there was an annual average reduction of $7.0 \%$ in IMR and of 9.3\% in PNMR; in the highlands, such reduction was of $3.9 \%$ in IMR and of $4.1 \%$ in PNMR. No statistically significant difference was observed between both altitudinal zones in the ST of the neonatal component. The risk of death up to 1 year old and in the post-neonatal period was significantly higher in the highlands (Table 1).

Table 2 shows clusters for IMR. Out of the 10 clusters that show significant differences from the NOA's overall IMR, values were higher only in 4 (Figure 2); the cluster with the greatest difference (cluster 1) includes districts from the highlands at an average altitude of 3161.7 MASL.
In this cluster, the RR of death is twice as high that of other clusters where IMR is higher than the NOA's overall IMR.

Table 3 describes clusters by RR of neonatal mortality. Significant differences from the NOA's NMR were identified in 12 clusters; among these, only 4 showed higher values. For example, cluster 4, which corresponds to districts in the highlands with an average altitude of 3007 MASL, recorded a NMR of $12.32 \%$ and a RR of 1.19 .

Finally, Table 4 shows clusters corresponding to post-neonatal mortality. Out of the 9 clusters identified as having a PNMR significantly different from the NOA's overall rate, rates and risks were higher in 4; it is worth noting that cluster 1 had a PNMR of $19.71 \%$, a RR of 3.76 , and is made up of districts in the highlands, with an average altitude of 3161.58 MASL

It is important to mention that, in Tables 2, 3 and 4 , almost all districts that have an RR below 1 (i.e., the risk is lower than in the NOA overall) correspond to the lowlands.

In the clusters of districts with an average altitude above 3000 MASL, the mortality rates and risks of death are 1.8 and 2.8 times higher for IMR and PNMR, respectively (Tables 2 and 4). However, the rates and risks observed in NMR clusters are rather consistent among one another, with an average difference of only 1.1.

\section{DISCUSSION}

This study evidences the great heterogeneity in infant mortality and its components observed in the NOA based on altitude. The reduction of the different rates at both altitudinal zones is progressive and consistent with what is occurring in the rest of Argentina; however, rates remain persistently higher in the highlands, especially PNMR. Several studies have pointed

TABLE 1. Spatial and temporal variation and relative risk of total infant mortality and its components (1998-2010)

\begin{tabular}{lccccccccccc}
\hline $\begin{array}{l}\text { Altitudinal } \\
\text { zone }\end{array}$ & $\begin{array}{c}\text { Live } \\
\text { births }\end{array}$ & $\begin{array}{c}\text { No. of } \\
\text { deaths }\end{array}$ & $\begin{array}{c}\text { IMR } \\
(\boldsymbol{\%})\end{array}$ & ST & RR & $\begin{array}{c}\text { NMR } \\
(\%)\end{array}$ & ST & RR & $\begin{array}{c}\text { PNMR } \\
(\%)\end{array}$ & ST & RR \\
\hline Highlands & 42005 & 1253 & $29.8^{*}$ & -0.039 & 0.73 & 12.1 & -0.038 & 0.73 & $17.7^{*}$ & -0.041 & 0.74 \\
Lowlands & 1265413 & 19824 & 15.6 & $-0.070^{* *}$ & 0.63 & 10.4 & -0.038 & 0.79 & 5.2 & $-0.093^{* *}$ & 0.54 \\
$\begin{array}{l}\text { Northwest region } \\
\text { of Argentina }\end{array}$ & 1307418 & 21077 & 16.1 & -0.042 & 0.71 & 10.44 & -0.038 & 0.73 & 5.6 & -0.048 & 0.71 \\
\hline
\end{tabular}

* Statistically significant differences between the highlands and the lowlands $(p<0.05)$.

** Statistically significant differences between the beginning and the end of the study period $(\mathrm{p}<0.05)$.

IMR: total infant mortality rate. NMR: neonatal mortality rate. PNMR: post-neonatal mortality rate.

ST: secular trend. RR: relative risk. 
TABLE 2. Characteristics of the 10 infant mortality clusters

\begin{tabular}{|c|c|c|c|c|c|c|}
\hline No. & Districts grouped by total infant mortality & $\begin{array}{c}\text { Live } \\
\text { births }\end{array}$ & $\begin{array}{l}\text { No. of } \\
\text { deaths }\end{array}$ & $\begin{array}{c}\text { IMR } \\
(\%)\end{array}$ & $\begin{array}{c}\text { Relative } \\
\text { risk }\end{array}$ & $\begin{array}{l}\text { Average } \\
\text { altitude }\end{array}$ \\
\hline 1 & $\begin{array}{l}\text { Rinconada, Santa Catalina, Cochinoca, Yavi, Iruya, Humahuaca, } \\
\text { Susques, Santa Victoria, Tilcara, Valle Grande, Tumbaya, Los Andes }\end{array}$ & 33002 & 1058 & 32.05 & 2.05 & 3161.67 \\
\hline 2 & Burruyacú, La Candelaria, Cruz Alta & 61557 & 1210 & 19.65 & 1.24 & 592 \\
\hline 3 & $\begin{array}{l}\text { Arauco, San Blas de los Sauces, Castro Barros, Capayán, Pomán, } \\
\text { Famatina, Sanagasta, Tinogasta }\end{array}$ & 127642 & 2295 & 17.97 & 1.13 & 1215 \\
\hline 4 & $\begin{array}{l}\text { Monteros, Famaillá, Simoca, Chicligasta, Leales, Río Chico, } \\
\text { Lules, Tafí del Valle }\end{array}$ & 104445 & 1842 & 16.77 & 1.11 & 620.6 \\
\hline 5 & Anta, Santa Bárbara, Gral. Güemes, San Pedro, Metán, La Caldera & 64525 & 862 & 13.33 & 0.82 & 737.6 \\
\hline 6 & Chicoana, Rosario de Lerma, Cerrillos & 24149 & 315 & 13.01 & 0.81 & 1356.3 \\
\hline 7 & Jiménez, Río Hondo & 17533 & 202 & 11.49 & 0.71 & 269.5 \\
\hline 8 & $\begin{array}{l}\text { San Martín, Loreto, Atamisqui, Silípica, Robles, Sarmiento, } \\
\text { Juan F. Ibarra, Santiago del Estero (capital) }\end{array}$ & 93622 & 1037 & 11.05 & 0.67 & 135.1 \\
\hline 9 & San Antonio & 2088 & 10 & 4.78 & 0.30 & 1345 \\
\hline 10 & Graneros & 37777 & 67 & 1.77 & 0.11 & 300 \\
\hline
\end{tabular}

IMR: infant mortality rate.

FIGURE 2. Relative risk of infant mortality

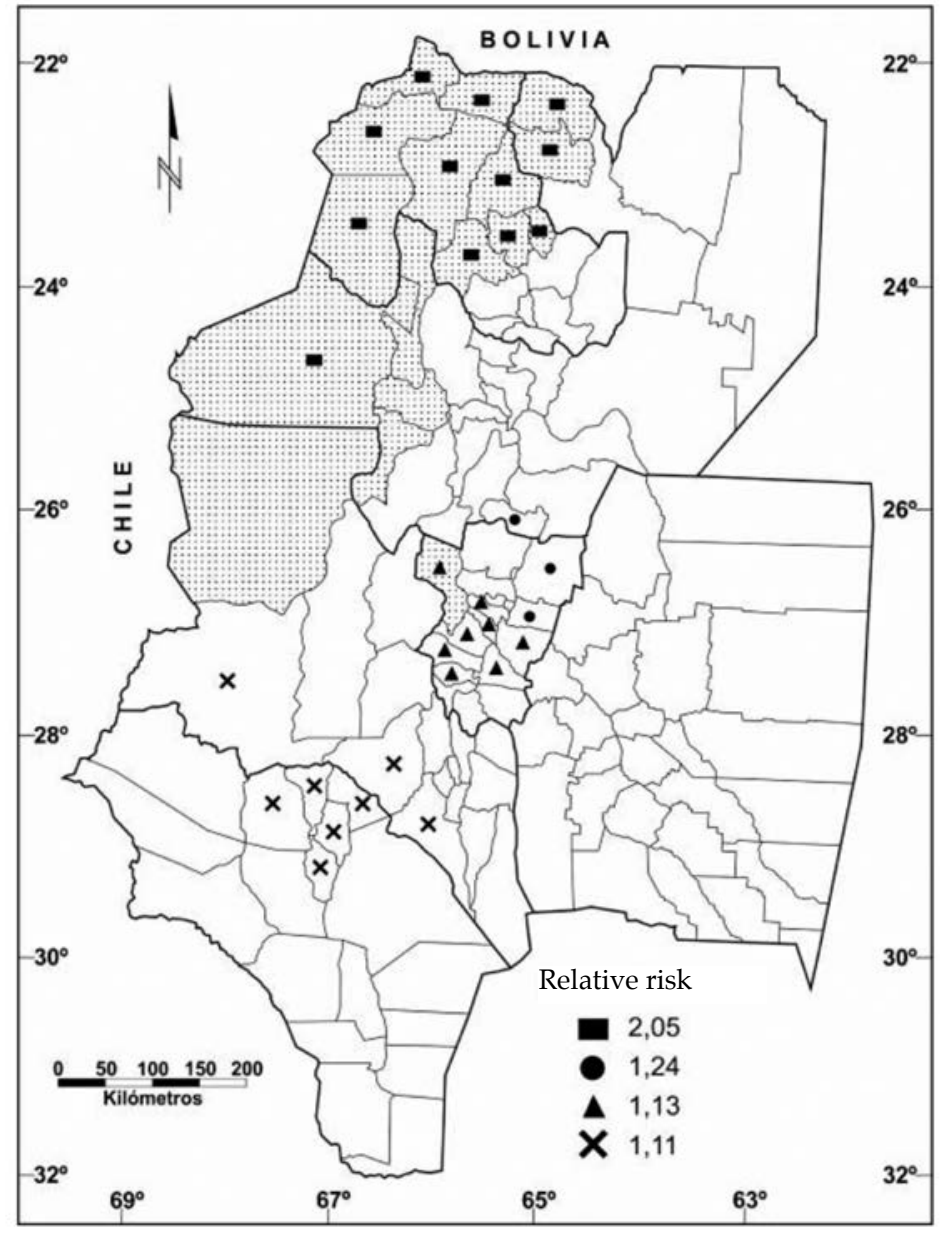

Districts at more than 2000 MASL

Districts at less than 2000 MASL 
out the increase in NMR along with altitude in different populations worldwide ${ }^{13-15,19}$ but there are practically no data on how PNMR relates to altitude.

Infant mortality is influenced and determined by a set of synergistic factors, such as cultural, environmental, demographic, biological, socioeconomic, geographic, and health carerelated factors. ${ }^{20}$ In general, ecology in highaltitude ecosystems anywhere in the world is complex and shapes the lives of inhabitants, either because of lack of oxygen, low temperatures, intense solar radiation, freezing during the night, low ambient humidity, usually infertile soil, and a steep terrain with isolated populations, poorly productive economies, and difficulties for accessing health care services (in general, because of distance) and information; all these factors lead to increased IMRs.

Niermeyer et al. ${ }^{21}$ compared IMRs from different countries; in some, up to $20 \%$ of the population lived at a high altitude. When comparing these data to those of our study, it is observed that IMR in the highlands $(29.8 \%$ ) is similar to that of Peru $(23 \%)$ and Bolivia (52\%o) whereas NMR $(12.1 \%$ ) is more similar to that of Colombia (14\%o), and both IMR and NMR are higher than the NOA's overall rates $(10.4 \%$ o $)(1998-2010)$.

TABLE 3. Characteristics of the 12 neonatal mortality clusters

\begin{tabular}{|c|c|c|c|c|c|c|}
\hline No. & Districts grouped by neonatal mortality & $\begin{array}{c}\text { Live } \\
\text { births }\end{array}$ & $\begin{array}{l}\text { No. of } \\
\text { deaths }\end{array}$ & $\begin{array}{c}\text { NMR } \\
(\%)\end{array}$ & $\begin{array}{c}\text { Relative } \\
\text { risk }\end{array}$ & $\begin{array}{l}\text { Average } \\
\text { altitude }\end{array}$ \\
\hline 1 & San Fernando del Valle de Catamarca, Fray Mamerto Esquiú & 44732 & 641 & 14.32 & 1.39 & 549.5 \\
\hline 2 & Burruyacú, La Candelaria, Cruz Alta & 61557 & 872 & 14.16 & 1.38 & 592 \\
\hline 3 & Monteros, Famaillá, Simoca, Chicligasta, Leales, Río Chico, Lules & 100536 & 1282 & 12.75 & 1.24 & 421.6 \\
\hline 4 & $\begin{array}{l}\text { Susques, Los Andes, Tilcara, Tumbaya, Humahuaca, Cochinoca, } \\
\text { Rinconada, La Poma, Manuel Belgrano }\end{array}$ & 81135 & 1000 & 12.32 & 1.19 & 3007.9 \\
\hline 5 & Santa Bárbara, San Pedro, Ledesma, General Güemes & 57975 & 481 & 8.29 & 0.79 & 575.5 \\
\hline 6 & General José de San Martín & 48989 & 355 & 7.25 & 0.69 & 490 \\
\hline 7 & $\begin{array}{l}\text { La Viña, Guachipas, Chicoana, Rosario de Lerma, Metán, San Carlos, } \\
\text { Cerrillos, Rosario de la Frontera }\end{array}$ & 47207 & 329 & 6.96 & 0.66 & 1215.4 \\
\hline 8 & $\begin{array}{l}\text { Salavina, Quebrachos, Ojo de Agua, Avellaneda, Atamisqui, Aguirre, } \\
\text { Mitre, General Taboada, Sarmiento, San Martín, Loreto, Juan F. Ibarra, } \\
\text { Belgrano, Robles, Silípica, Figueroa, Santiago del Estero (capital) }\end{array}$ & 126792 & 841 & 6.23 & 0.61 & 150.5 \\
\hline 9 & Jiménez, Río Hondo & 17533 & 109 & 6.21 & 0.59 & 269.5 \\
\hline 10 & Rivadavia, Anta & 27981 & 169 & 6.03 & 0.57 & 281 \\
\hline 11 & San Antonio & 2088 & 5 & 4.6 & 0.23 & 1345 \\
\hline 12 & Graneros & 37777 & 42 & 11.12 & 0.10 & 300 \\
\hline
\end{tabular}

NMR: neonatal mortality rate.

TABLE 4. Characteristics of the 9 post-neonatal mortality clusters

\begin{tabular}{|c|c|c|c|c|c|c|}
\hline No. & Districts grouped by post-neonatal mortality & $\begin{array}{c}\text { Live } \\
\text { births }\end{array}$ & $\begin{array}{l}\text { No. of } \\
\text { deaths }\end{array}$ & $\begin{array}{c}\text { PNMR } \\
(\%)\end{array}$ & $\begin{array}{l}\text { Relative } \\
\text { risk }\end{array}$ & $\begin{array}{l}\text { Average } \\
\text { altitude }\end{array}$ \\
\hline 1 & $\begin{array}{l}\text { Rinconada, Santa Catalina, Cochinoca, Yavi, Iruya, Humahuaca, } \\
\text { Susques, Santa Victoria, Tilcara, Valle Grande, Tumbaya, Los Andes }\end{array}$ & 33002 & 651 & 19.71 & 3.76 & 3161.6 \\
\hline 2 & Rosario de la Frontera, Anta, Copo, Santa Bárbara, Orán & 87313 & 696 & 7.57 & 1.46 & 527.6 \\
\hline 3 & $\begin{array}{l}\text { Antofagasta de la Sierra, Molinos, Cafayate, San Carlos, Santa María, } \\
\text { Cachi, Belén, Tafí del Valle, La Poma, La Viña, Guachipas, Andalgalá, } \\
\text { Trancas, Chicoana, Rosario de Lerma, Tinogasta }\end{array}$ & 63127 & 480 & 7.16 & 1.38 & 1646.8 \\
\hline 4 & $\begin{array}{l}\text { Aguirre, Mitre, Belgrano, Salavina, General Taboada, Quebrachos, } \\
\text { Avellaneda, Rivadavia, Ojo de Agua, Sarmiento, Atamisqui, } \\
\text { Juan F. Ibarra, San Martín, Moreno, Loreto, Robles, Silípica, Figueroa }\end{array}$ & 72490 & 510 & 7.04 & 1.27 & 126.8 \\
\hline 5 & Palpalá, Dr. Manuel Belgrano, El Carmen, San Antonio, San Pedro & 120110 & 572 & 4.8 & 0.84 & 1110.4 \\
\hline 6 & Tafí Viejo, Yerba Buena & 46995 & 193 & 4.11 & 0.72 & 528 \\
\hline 7 & Capayán, San Fernando del Valle de Catamarca, Valle Viejo & 52849 & 210 & 3.97 & 0.70 & 843 \\
\hline 8 & Santiago del Estero (capital) & 65178 & 254 & 3.9 & 0.68 & 182 \\
\hline 9 & Graneros & 37777 & 25 & 6.62 & 0.11 & 300 \\
\hline
\end{tabular}

PNMR: post-neonatal mortality rate. 
The influence of the above-mentioned factors on infant mortality varies depending on the period when death occurs. In the neonatal period, prevalent causes of death are those related to congenital conditions (malformations) and health care (maternal health, antenatal care, care provided during labor, and infant care during the first days of life). In the post-neonatal period, mortality is mostly caused by exogenous factors, environmental and socioeconomic conditions affecting infant health. Based on the high PNMR observed in the highlands of the NOA, it is possible to hypothesize that, in these regions -and excluding hypoxia-, many infant deaths are caused by preventable causes (malnutrition and infectious diseases).

In the post-neonatal period, these rates are closely related to the socioeconomic development of the populations. The NOA is a region with a low economic development and a high poverty index, as well as major disadvantages compared to other regions of Argentina. In terms of economy, the NOA -particularly Jujuy, Santiago del Estero, Catamarca, and La Rioja- is characterized by intermediate development, a marked delay in terms of production and business, a high level of informality, minor investments, and a human development index (HDI) below that of any other Argentine province. ${ }^{20,22}$ Compared to the Autonomous City of Buenos Aires, where the HDI was 0.864 , and to the national HDI average of 0.798 in 2001, all NOA provinces are below these values: Jujuy (0.767), Salta (0.768), Tucumán (0.764), Santiago del Estero (0.766), Catamarca (0.789), and La Rioja (0.775). ${ }^{23}$ Such interprovincial gap in socioeconomic development widens when the analysis focuses on smaller territorial organizations, districts, or sub-regions. At this level of analysis, the Index of Material Deprivation and Unmet Basic Needs shows alarming values, more precisely, in the districts located at higher altitudinal zones.

A more favorable economic situation in the lowlands may account, in part, to a RR below 1 in these districts.

There are other factors that may also account for the higher mortality observed in high-altitude environments. Pregnancies in these settings are associated with a reduced blood flow to the uterine artery, increased uteroplacental resistance, alterations in the expression of placental factors, chronic hypoxia, and vascular changes. ${ }^{24}$ These characteristics have resulted in different pregnancy adverse outcomes, including intrauterine growth restriction, reduced birth weight, fetal death, and preeclampsia.

Some authors, for example Giussani et al., ${ }^{25}$ have established that the effect of altitude on birth weight is independent from socioeconomic status. Various backgrounds indicate that births occurring in the districts located at a higher altitude in the provinces of Catamarca and Jujuy have a significantly lower average birth weight than those living closer to sea level. ${ }^{26-30}$

Birth before 37 weeks of gestation is the main universal cause of perinatal morbidity and mortality. ${ }^{24}$ However, the relevance of this situation in high-altitude populations is conflicting. Levine et al. ${ }^{24}$ have not found an increase in the rate of preterm births in a sample from Peru obtained from the Perinatal Information System. In the province of Jujuy, and using the same source, Grandi et al. ${ }^{30}$ have demonstrated that the prevalence of prematurity, small for gestational age infants, and mild and severe intrauterine growth restriction are increasingly related to high-altitude; the latter two factors are even, significantly, twice as high in the Puna than in Maternidad Sardá, a maternity center located at sea level. Candelas et al. ${ }^{31}$ reach the same conclusion when analyzing birth weight in the province of Catamarca, and they establish that the increased incidence of preterm births caused by a higher altitude above sea level may account for an adaptive advantage of preterm delivery in these conditions.

Finally, other cultural and physiological factors, which are related to one another, may account for the higher infant mortality observed in high-altitude environments. A study conducted in Tyrol (Austria) identified the altitude of the place of residence as a significant predictor of risk for sudden death, especially when combined with the prone sleeping position. ${ }^{32}$ This association may be explained by a set of factors that are also present in high-altitude Andean ecosystems: respiratory disorders, reduced oxygen saturation, and lower ambient temperature. Alduncin et al. ${ }^{33}$ conducted a study in San Antonio de los Cobres (3775 MASL), in the province of Salta, regarding healthy children's sleeping habits, and found that the population had chronic hypoxemia, similar to high-altitude populations of Peru and Bolivia. In relation to sleeping habits, the authors observed that children shared a llama or sheep's wool or skin mattress with their parents or, exceptionally, slept in the prone position and were covered with several blankets. The authors concluded 
that the high percentage of sudden infant death was associated with hypobaric hypoxia caused by high-altitude, hypothermia or excessive use of warm clothing, infant's specific vulnerability to respiratory tract infections, and unsafe cosleeping habits.

To understand the extent to which these factors affect infant mortality, it would be worth to analyze its causes and identify whether they are specific to each altitudinal zone so as to design and implement health care policies aimed at reducing infant mortality in these specific ecosystems.

\section{CONCLUSIONS}

The IMR was higher among the populations from the highlands of the NOA, especially total infant mortality and its post-neonatal component. The ST reduced gradually but significantly throughout the study period. The cluster analysis showed that districts located in the highlands posed a higher risk for infant death.

\section{Funding}

For projects called "Geographic differentiation in the Argentine population structure: surnames, genetics, and demographics", by the Department of Science and Technology and Regional Studies (Secretaría de Ciencia y Técnica y Estudios Regionales) of Universidad Nacional de Jujuy (SECTER-UNJu) (period 2016-2019), and "Genetic and anthropological aspects among populations from the Northwest region of Argentina: regional and temporal variation", SECTER-UNJu (period 2012-2015).

\section{REFERENCES}

1. Abeya Gilardón E. La mortalidad infantil en Argentina: necesidad de focalizar acciones por riesgo social y biomédico. Arch Argent Pediatr 1995;93(5):291-9.

2. Bhem H. Determinantes económicos y sociales de la mortalidad en América Latina. Salud Colectiva 2011;7(2): 231-51.

3. Bolsi A, Paolasso P, Longhi F. El Norte Grande argentino entre el progreso y la pobreza. Poblac Soc 20052006;12/13:231-70.

4. Mazzeo V. La mortalidad infantil en Argentina. Análisis de sus cambios y de las diferencias regionales. Población y Desarrollo - Argonautas y caminantes 2015;10:9-20.

5. Organización Mundial de la Salud. Informe sobre la salud en el mundo 2003. Suiza, 2003. [Accessed on: June $\left.20^{\text {th }}, 2016\right]$. Available at: http:/ / apps.who.int/iris/ bitstream/10665/42822/1/9243562436.pdf.

6. UNICEF. El estado de la salud materna, neonatal e infantil en la Argentina. 2014. [Accessed on: February 23 ${ }^{\text {rd }}, 2017$ ]. Available at: https: / / studylib.es/ doc/7667892/ el-estadode-la-salud-materna--neonatal-e-infantil-en-argentina.

7. Bolsi A.Poblacióny territorio del noroesteargentinodurante el sigloXX. Travesía (San Miguel de Tucumán) 2004;7 / 8: 9-52.

8. Lichty J, Ting R, Bruns $\mathrm{P}$, et al. Studies of babies born at high altitude. I. Relation of altitude to birth weight. $A M A$ J Dis Child 1957;93(6):666-9.

9. Frisancho AR, Cossman J. Secular trend in neonatal mortality in the mountain states. Am J Phys Anthropol 1970;33(1):103-5.

10. McCullough R, Reeves J. Fetal growth retardation and increased infant mortality at high altitude. Arch Environ Health 1977;32(1):36-9.

11. González G. Impacto de la altura en el embarazo y en el producto de la gestación. Rev Peru Meda Exp Salud Pública 2012;29(2):242-9.

12. PAHO. Health conditions in the Americas. (Scientific Publication No. 549). Washington, DC: WHO; 1994. [Accessed on: June 1 $\left.{ }^{\text {st }}, 2016\right]$. Available at http:/ / iris.paho. org / xmlui / handle/123456789/28371?show=full.

13. Keyes L, Armaza J, Niermeyer S, et al. Intrauterine growth restriction, preeclampsia, and intrauterine mortality at high altitude in Bolivia. Pediatr Res 2003;54(1):20-5.

14. Huicho L, Trelles M, Gonzales F. National and sub-national under-five mortality profiles in Peru: a basis for informed policy decisions. BMC Public Health 2006;6:173.

15. Wiley A. Neonatal size and infant mortality at high altitude in the western Himalaya. Am JPhys Anthropol 1994;94(3):289305.

16. Corte AE, Espizua LE. Inventario de glaciares de la cuenca del Río Mendoza. Mendoza: IANIGLA-CONICET; 1981. Pages 5-62.

17. Pontussi EP. Geografía del Noroeste Argentino. Salta: Facultad de Ciencias Naturales. Universidad Nacional de Salta; 1995.

18. Kulldorf M. SaTScanTM User Guide for version 9.4. 2015. [Accessed on: February 23 ${ }^{\text {rd }}$, 2017]. Available at: https:/ / www.satscan.org/cgi-bin/satscan/register.pl/SaTScan_ Users_Guide.pdf?todo=process_userguide_download.

19. Mazess R. Neonatal mortality and altitude in Peru. Am J Phys Anthropol 1965;23(3):209-13.

20. Ministerio de Salud. Análisis de la Mortalidad Materno Infantil. República Argentina, 2003-2012. Ministerio de Salud; 2016. [Accessed on: June $4^{\text {th }}, 2016$ ]. Available at: http: / / www.msal.gob.ar/images/stories/bes / graficos / $0000000616 \mathrm{cnt}$-analisis_mortalidad_materno_ infantil_argentina-2003-2012.pdf.

21. NiermeyerS, Andrade MollinedoP,Huicho L. Child health and living at high altitude. Arch Dis Child 2009;94(10): 80611.

22. Cao H, Vaca J. Desarrollo regional en la Argentina: la centenaria vigencia de un patrón de asimetría territorial. Eure 2006;32(95):95-111.

23. PNUD. Informe nacional sobre desarrollo humano 2013. Argentina en un mundo incierto: Asegurar el desarrollo humano en el siglo XXI. Buenos Aires: Programa Naciones Unidas para el Desarrollo; 2013. [Accessed on: February 20 ${ }^{\text {th }}$, 2017]. Available at: ttp://www.ar.undp. org/content/argentina/es / home/library/human development/inform e-nacional-sobre-desarrollohumano-20 13--argentina-en-un-m.html.

24. Levine L, Gonzales G, Tapia V, et al. Preterm birth risk at high altitude in Peru. Am JObstet Gynecol 2015;212(12): 210. e1-8.

25. Giussani D, Phillips P, Anstee S, et al. Effects of altitude versus economic status on birth weight and body shape at birth. Pediatr Resh 2001;49(4):490-4.

26. Álvarez P, Dipierri J, Bejarano L, et al. Variación altitudinal del peso al nacer en la provincia de Jujuy. Arch Argent Pediatr 2002;100(6):440-7. 
27. Moreno Romero S, Marrodán M, Dipierri J. Peso al nacimiento en ecosistemas de altura. Noroeste argentino: Susques. Observat Medioamb 2003;6:161-76.

28. Lomaglio D, Marrodán M, Verón J, et al. Peso al Nacimiento en Comunidades de Altura de la Puna Argentina: Antofagasta De La Sierra (Catamarca). Antropo (Bilbao) 2005;9:61-7.

29. Bejarano I, Alfaro E, Dipierri J, et al. Variabilidad interpoblacional y diferencias ambientales, maternas y perinatales del peso al nacimiento. Rev Hosp Matern Infant Ramón Sarda 2009;28(1):29-39.

30. Grandi C, DipierriJ, Luchtenberg G, etal. Efecto de la altitud sobre el peso al nacer y eventos perinatales adversos en dos poblaciones argentinas. Rev Fac Cienc Méd (Córdoba) 2013;70(2):55-62.

31. Candelas N, Terán J, López Barbancho D, et al. Altitude effect on birth weight and prematurity in the Province of Catamarca (Argentina). Am J Hum Biol 2015;27(4):526-9.

32. Kohlendorfer U, Kiechl S, Sperl W. Living at high altitude and risk of sudden infant death syndrome. Arch Dis Child 1998;79(6):506-9.

33. Alduncin J, Grañana N, Follett F, et al. Problemas respiratorios durante el sueño en lactantes nativos del altiplano argentino. Arch Argent Pediatr 2005;103(1):14-22. 